\title{
Sposoby i możliwości ujmowania wód podziemnych na obszarach masywów krystalicznych - na przykładzie granitu Karkonoszy
}

\author{
Mirosław Wąsik ${ }^{1}$, Henryk Marszałek ${ }^{1}$, Michał Rysiukiewicz ${ }^{1}$, Lech Poprawski ${ }^{1}$
}

\begin{abstract}
Possibilities of groundwater abstraction in areas of crystalline massifs - a case study of the Karkonosze granite. Prz. Geol., 68: 263-270; doi: 10.7306/2020.14

A b s tra ct. The article presents an overview of various types of water intakes in the area of the Karkonosze granite massif, with their characteristics and possibilities of use, considering well discharge rates, stability, and water quality. For this purpose, the results of scientific research carried out by the authors in various years, including numerical modelling, were used. Analysis of the water-bearing capacity of the granite massif and intakes work indicates that the construction of a large groundwater intake, covering the needs of even medium-sized cities, could be difficult. Higher discharges are possible for surface and drainage water intakes, but located near a large river. Small towns can be supplied by mixed surface-drainage intakes based on the waters of minor rivers. For small households, the best solution is to make 1-2 well intakes to a depth of 60-100 m, or a spring intake.
\end{abstract}

Keywords: water intake, hard rocks, Karkonosze granite

Zasobność wodna wyniesionych masywów krystalicznych Sudetów jest ściśle uzależniona od stopnia spękania utworów skalnych i od wielkości infiltracji efektywnej. Duża zmienność występowania w profilu spękanych stref wodonośnych o zróżnicowanej pojemności determinuje sposób ich ujmowania w celu zaopatrzenia miejscowej ludności w wodę pitną. Skały krystaliczne charakteryzują się słabszym zawodnieniem w porównaniu ze skałami osadowymi. Stwarza to gorsze warunki do budowy pionowych ujęć wód podziemnych, szczególnie o dużej wydajności, niezbędnych do zaopatrzenia większych miejscowości. W takiej sytuacji wykorzystuje się inne rozwiązania, polegające na budowie ujęć bazujących przeważnie na wodach powierzchniowych oraz wodach podziemnych występujących w strefie zwietrzelinowej skał krystalicznych. Do dominujących należą ujęcia wód rzecznych i ujęcia drenażowe. Większe otworowe ujęcia wód podziemnych w utworach krystalicznych należą do rzadkości. Stosuje się je do ujmowania wód poziomów czwartorzędowych, zalegających na utworach krystalicznych głównie w dolinach rzecznych. Taka struktura ujęć powoduje, że stabilność zaopatrzenia w wodę jest silnie uzależniona od zasilania przez opady atmosferyczne.

W ostatnich latach coraz głośniej mówi się o ociepleniu klimatu. Wyniki badań (Miętus i in., 2011) wskazują, że do 2100 r. w Polsce średnia roczna temperatura powietrza wzrośnie o $0,35^{\circ} \mathrm{C}-0,5^{\circ} \mathrm{C}$. Ocieplenie klimatu przyczyni się do zmniejszenia zasilania wód podziemnych - aby zrównoważyć spadek zasobów tych wód, roczne sumy opadów atmosferycznych powinny wzrosnąć o $30 \mathrm{~mm}$ (Ziernicka, 2004). Tymczasem prognozy zmian wysokości opadów atmosferycznych, chociaż nie sąjednoznaczne, jednak wskazują raczej na ich utrzymanie na dotychczasowym poziomie. Zupełnie innym problemem jest zróżnicowanie wielkości opadów w ciągu roku. Pojawiające się coraz częściej okresy suszy będa powodowały wzrost deficytu wody. W Sudetach jego pierwsze objawy zaczęły się pojawiać już pod koniec lat 80. ubiegłego stulecia (Staśko i in., 2008). Zarejestrowane w 2003 r. skrajnie niskie wartości natężenia przepływu rzek, będące efektem suszy, spowodowały prawie 3-krotny spadek odnawialnych zasobów wód pod- ziemnych (Marszałek, 2007). Z problemami zaopatrzenia w wodę od lat zmaga się powiat jeleniogórski, którego przeważająca część znajduje się na obszarze plutonu karkonoskiego, stanowiącego część masywu karkonosko-izerskiego (Żelaźniewicz i in., 2011). W ostatnich latach na obszarze tym, podobnie jak w innych rejonach Sudetów, znacząco zaczyna spadać wydajność ujęć wód powierzchniowych. Część indywidualnych gospodarstw oraz mniejszych podmiotów gospodarczych, nie mogąc liczyć na regularne dostawy wody, decyduje się na budowę własnych ujęć wód podziemnych i to głębszego krążenia.

Analizowany obszar występowania granitu karkonoskiego (ryc. 1) znajduje się w Sudetach Zachodnich, które są w Polsce jednym z rejonów najliczniej odwiedzanych przez turystów. Spadek wydajności ujęć wód na tym obszarze, szczególnie w warunkach postępujących zmian klimatycznych, przejawiających się częstym występowaniem długotrwałych, kilkutygodniowych okresów niżówkowych, powoduje brak zaspokojenia istniejących potrzeb i prowadzi do sytuacji konfliktowych w miejscowościach wypoczynkowych. Wymusza to poszukiwanie innych rozwiązań umożliwiających pozyskanie wody. Większość gmin i miast tego regionu stara się uniezależnić od całkowitego poboru wód z ujęć powierzchniowych i drenażowych.

W niniejszym artykule dokonano analizy wydajności oraz możliwości wykorzystania różnych rodzajów ujęć wody wykonanych na obszarze masywu granitowego Karkonoszy. Ze względu na stale powiększający się deficyt wody problem technik ujmowania wód podziemnych w obszarach górskich, poruszany m.in. przez Staśkę i Wojtkowiaka (2004), jest nadal aktualny.

\section{CHARAKTERYSTYKA KARKONOSKIEGO ZBIORNIKA WÓD PODZIEMNYCH}

Z występujących w Sudetach intruzji granitowych największe rozprzestrzenienie ma granit Karkonoszy. Zawodnienie granitu jest bardzo zróżnicowane zarówno w ujęciu

\footnotetext{
${ }^{1}$ Instytut Nauk Geologicznych, Uniwersytet Wrocławski, pl. Maksa Borna 9, 50-204 Wrocław; miroslaw.wasik@uwr.edu.pl; henryk.marszalek@uwr.edu.pl; michal.rysiukiewicz@uwr.edu.pl; lech.poprawski@uwr.edu.pl
} 
przestrzennym, jak i głębokościowym. Anizotropia ośrodka skalnego wiąże się głównie ze stopniem spękania masywu, wpływającym na jego wodonośność. Liczba stref wodonośnych, uwarunkowana szczelinowatością skał, może się zmieniać na stosunkowo niedużym obszarze. W otworach do głębokości $100 \mathrm{~m}$ występuje jedna lub kilka stref, niekiedy połączonych hydraulicznie, charakteryzujących się zróżnicowaną wodonośnością i właściwościami fizykochemicznymi wód (Marszałek, 2007; Marszałek, Wąsik, 2005).

Największą zasobnością cechuje się pierwszy od powierzchni terenu zbiornik wód porowo-szczelinowych, obejmujący strefę szczelin wietrzeniowych (do głębokości 20-30 m) wraz z zalegającymi na niej pokrywami zwietrzelin. Z niego czerpie wodę większość ujęć wód podziemnych. W opracowaniach regionalnych zbiornik ten przyjmuje nazwę zbiornika karkonoskiego (m.in. Janicki i in., 1994; Zaleska i in., 1999; Marszałek, 2007). Na początku lat 90. ubiegłego wieku był on zaliczany do Głównych Zbiorników Wód Podziemnych Polski (GZWP nr 344 Zbiornik Karkonosze), o zasobach dyspozycyjnych $3,86 \mathrm{dm}^{3} /\left(\mathrm{s} \times \mathrm{km}^{2}\right)$ (Kleczkowski, 1990), jednak ze względu na niski odczyn wód pod koniec lat 90. usunięto go z rejestru GZWP. Wśród trzech podstawowych stref wodonośnych, wydzielanych w całym krystaliniku sudeckim, zbiornik ten reprezentuje pierwszą, najpłytszą strefę aktywnej wymiany wód (Kowalski, 1992; Marszałek, 2007; Staśko, Tarka, 2002). Jej wodonośność jest uzależniona od stopnia spękania masywu, determinującego jej miąższość, rozprzestrzenienie oraz wielkość parametrów hydrogeologicznych ośrodka skalnego, i ściśle związana z czynnikami hydrometeorologicznymi i geomorfologicznymi.

Zmienna miąższość strefy aeracji wynosi od kilkudziesięciu centymetrów do nawet kilkunastu i więcej metrów. Im bliżej stref wododziałowych, tym bardziej wzrasta

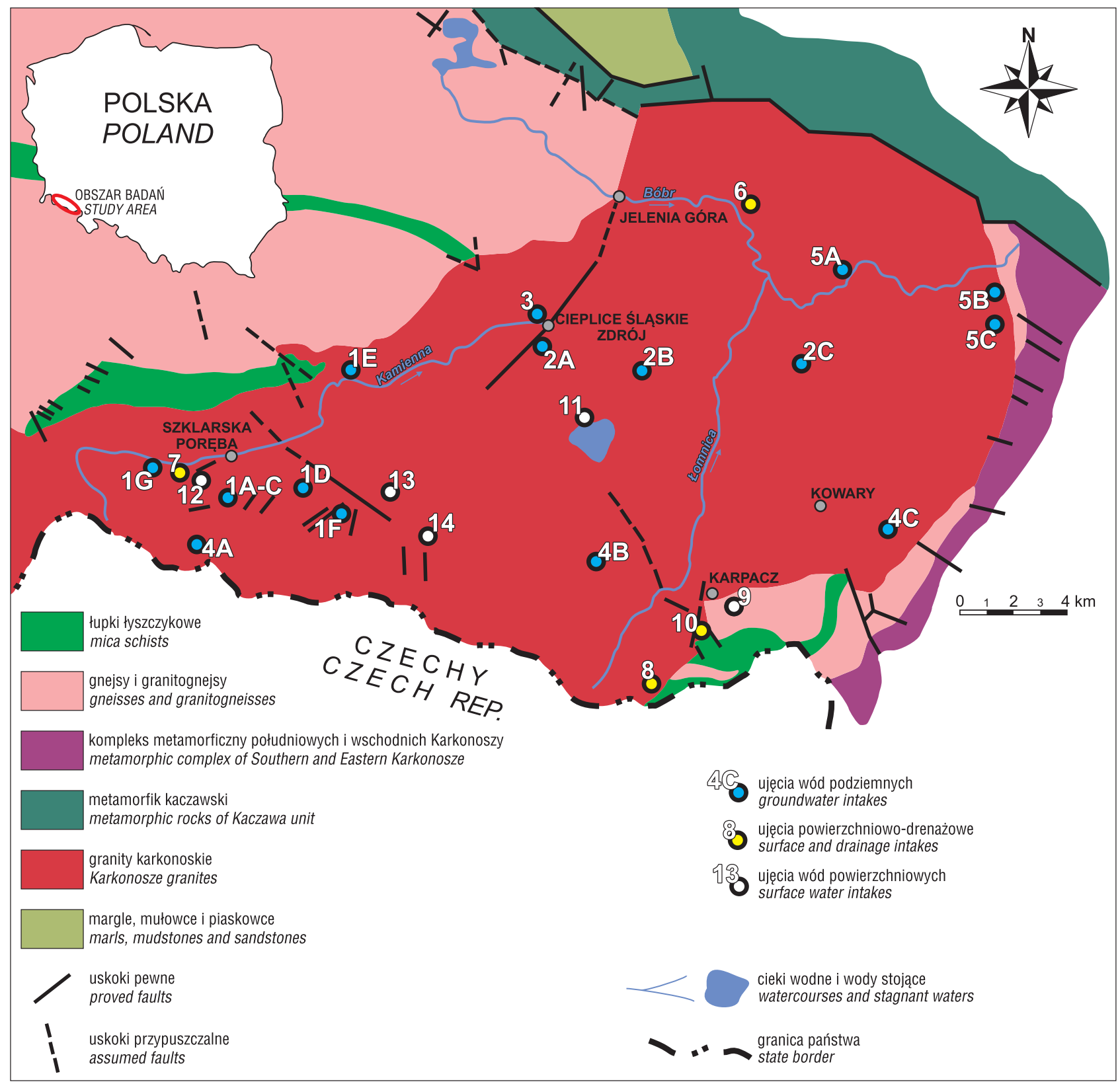

Ryc. 1. Lokalizacja wybranych ujęć wody na tle budowy geologicznej masywu karkonoskiego (mapa wg Kozdrój i in., 2001 - zmieniona) Fig. 1. Location of selected water intakes on the geology background of the Karkonosze Massif (map after Kozdrój et al., 2001 - changed) 
głębokość zalegania pierwszego od powierzchni terenu zwierciadła wód podziemnych (Marszałek, 2007). Strefę aktywnej wymiany wód podziemnych cechują najwyższe wartości parametrów filtracyjnych. Wartości współczynnika filtracji przekraczają nawet $87 \mathrm{~m} / \mathrm{d}$, a wielkości modułów odpływu podziemnego w skrajnych przypadkach w najwyżej położonych zlewniach Karkonoszy wynoszą $10-15 \mathrm{dm}^{3} /\left(\mathrm{s} \times \mathrm{km}^{2}\right)$. Na tak wysokie wskaźniki zasobów odnawialnych wpływa zarówno intensywne spękanie granitu w górnej, przypowierzchniowej części, jak i duża infiltracja efektywna, a także opady atmosferyczne przekraczające w grzbietowych partiach Karkonoszy 1300 mm/r.

Wyraźnie zaznaczające się w morfologii masywu strefy zrównań grzbietowych i stokowych, występujące na różnych poziomach, tworzą dogodne warunki do zasilania wód podziemnych. Silne rozcięcie morfologiczne granitu w jego górskiej, karkonoskiej, części sprzyja wypływom licznych źródeł, najczęściej o małej wydajności, w okresach suchych wynoszącej od 0,1 do $0,5 \mathrm{dm}^{3} / \mathrm{s}$, a w czasie roztopów wiosennych nawet powyżej $16 \mathrm{dm}^{3} / \mathrm{s}$ (Marszałek, 2007). Przepuszczalność szczelinowatego granitu, na głębokości kilkudziesięciu metrów określana za pomocą próbnego pompowania, jest raczej niska i wynosi średnio 0,1-0,9 m/d. Jego przewodność hydrauliczna mieści się głównie w przedziale $1-40 \mathrm{~m}^{2} / \mathrm{d}$ (ryc. 2) i rzadko przekracza $100 \mathrm{~m}^{2} / \mathrm{d}$ (Marszałek, 2007). Wydajność pojedynczych studni zmienia się w szerokim zakresie - od 0,1 do $25 \mathrm{~m}^{3} / \mathrm{h}$, zwykle nie przekracza $3 \mathrm{~m}^{3} / \mathrm{h}$ (Marszałek, Wąsik, 2002).

Zbiorniki wód porowych w dnie Kotliny Jeleniogórskiej są najlepiej wykształcone w czwartorzędowych utworach piaszczysto-żwirowych w dolinie Bobru, Kamiennej i Łomnicy. Ze względu na większą zasobność w porównaniu $\mathrm{z}$ otoczeniem stanowią poziomy użytkowe o miąższości od kilku do ponad 19 m w centrum kotliny (Marszałek, 2007). Tworzą one czwartorzędowy zbiornik wód podziemnych Jelenia Góra, w warstwie wodonośnej o miąższości 5-10 $\mathrm{m}$ i zróżnicowanych parametrach filtracyjnych. Współczynniki filtracji zmieniają się w nim od ok. 2 do ponad $1200 \mathrm{~m} / \mathrm{d}$, najczęściej w przedziale $10-100 \mathrm{~m} / \mathrm{d}$, a wodoprzewodność od kilkudziesięciu do $1000 \mathrm{~m}^{2} / \mathrm{d}$, a w

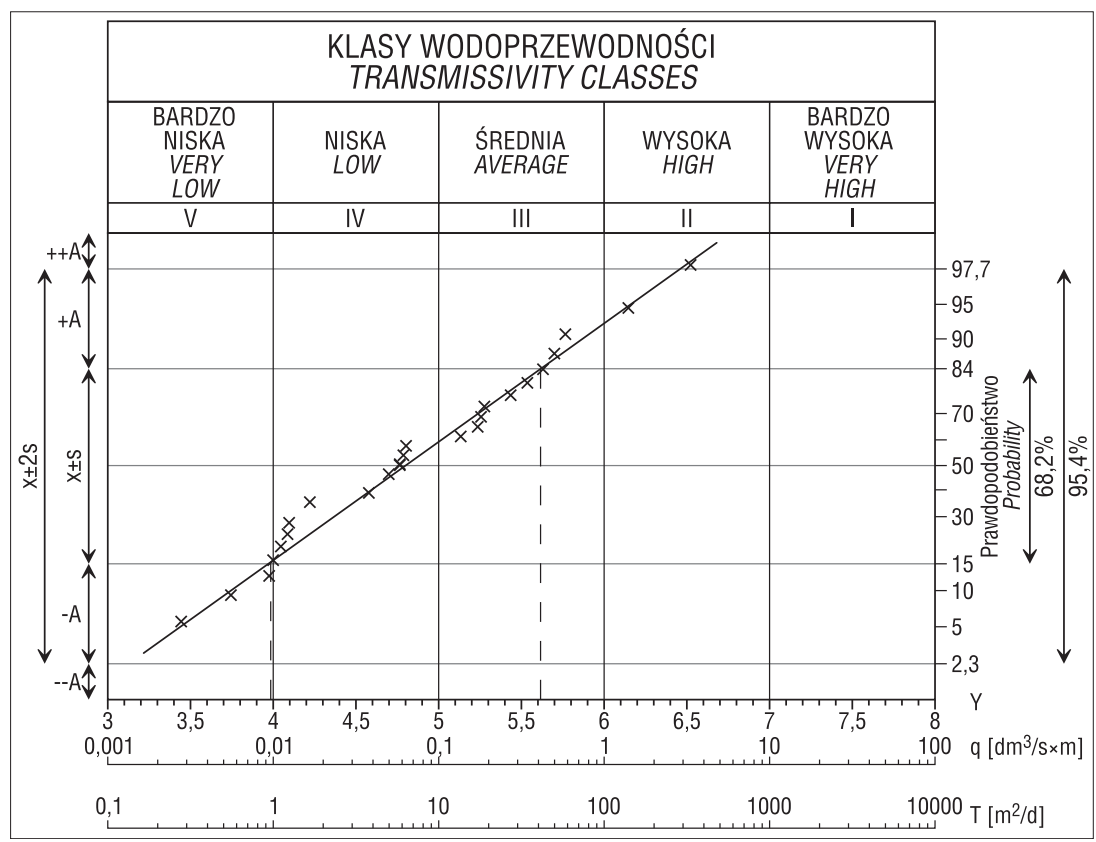

skrajnych przypadkach nawet kilku tysięcy $\mathrm{m}^{2} / \mathrm{d}$. Przeważnie jednak wynoszą 100-500 $\mathrm{m}^{2} / \mathrm{d}$ (Marszałek, 2007). Wysokie wartości parametrów filtracyjnych przekładaja się na wydajność otworów studziennych, która lokalnie osiąga ponad $90 \mathrm{~m}^{3} / \mathrm{h}$. Większość studni charakteryzuje się jednak wydajnością nieprzekraczającą $10 \mathrm{~m}^{3} / \mathrm{h}$.

\section{METODYKA}

W pracy wykorzystano wyniki własnych badań naukowych, wykonanych na obszarze krystaliniku karkonosko-izerskiego w różnych latach, w tym dane oraz wyniki modeli numerycznych opracowanych w celu oceny zasobów eksploatacyjnych ujęcia wody Grabarów w Jeleniej Górze, a także możliwości wykorzystania do budowy ujęć w Kotlinie Jeleniogórskiej czwartorzędowego piętra wodonośnego (Marszałek, Wąsik, 2012; Marszałek i in., 2008). Pomocne były również opracowania przeglądowe zawierające informacje o ujęciach wód podziemnych w masywie granitowym Karkonoszy (Błachuta i in., 2016; Marszałek, 2007). Jesienią 2019 r. przeprowadzono testy hydrogeologiczne w otworach badawczych zlokalizowanych na stokach Karkonoszy. Polegały one na wykonaniu krótkotrwałych pompowań, zalewań badawczych otworu oraz obserwacji wzniosu zwierciadła wody po zaprzestaniu pompowania. Pozwoliły one ustalić wydajność otworu, wydatek jednostkowy oraz obliczyć wartość współczynnika filtracji.

\section{WAŻNIEJSZE UJĘCIA WODY W OBSZARZE WYSTĘPOWANIA GRANITU KARKONOSKIEGO}

Ze względu na znaczną liczbę stałych mieszkańców i intensywny ruch turystyczny obszar wychodni granitu karkonoskiego w Kotlinie Jeleniogórskiej, wyniesionego morfologicznie grzbietu Karkonoszy oraz zachodnich stoków Rudaw Janowickich należy do części Sudetów o dużym zapotrzebowaniu na wodę. Największym ośrodkiem miejskim jest w nim Jelenia Góra (ok. 80 tys. mieszkańców), stanowiąca centrum przemysłowo-turystyczne i ośrodek komunikacyjno-usługowy regionu. $\mathrm{W}$ jej otoczeniu znajduje się wiele miejscowości wypoczynkowych, licznie odwiedzanych przez turystów. Należą do nich m.in. Karpacz, Szklarska Poręba, Kowary, Podgórzyn, Piechowice i Janowice Wielkie. W granicach miasta znajdują się również Cieplice Śląskie-Zdrój, które są jednym z najstarszych polskich uzdrowisk, wykorzystujących wody termalne. Zaopatrzenie w wodę ludności

\section{$\longleftarrow$}

Ryc. 2. Wodoprzewodność granitu karkonoskiego (Marszałek, 2007 - zmieniona)

Fig. 2. Transmissivity of Karkonosze granite (after Marszałek, 2007 - modified) 
regionu, szacowanej na ponad 200 tys. osób, wymaga ujmowania zarówno wód podziemnych, jak i powierzchniowych. Wody powierzchniowe są ujmowane ze zbiornika retencyjnego Sosnówka oraz z sieci rzek i potoków, w tym Bobru. Zdecydowana większość studni wierconych i kopanych ujmuje wodę z utworów czwartorzędowych wypełniających współczesne doliny głównych rzek (Bobru i jego karkonoskich dopływów, czyli Kamiennej i Łomnicy). Studnie zaopatrują w wodę przede wszystkim Jelenią Górę, natomiast miejscowości położone w górskiej części obszaru bazują na ujęciach wód potoków górskich i ujęciach drenażowych, a rzadziej na źródłach oraz studniach wierconych i kopanych.

Obecnie mieszkańcy Kotliny Jeleniogórskiej i otaczających ją masywów górskich są zaopatrywani w wodę pobieraną za pomocą ujęć powierzchniowych, infiltracyjnych i podziemnych. Ujęcia te eksploatują wody zwykłe, o mineralizacji poniżej $500 \mathrm{mg} / \mathrm{dm}^{3}$, z zastosowaniem różnych rozwiązań technicznych. Do ujmowania wód podziemnych są wykorzystywane studnie pionowe (szybowe, wiercone), poziome (drenaże) i studnie kombinowane (infiltracyjne), a wody powierzchniowe są ujmowane z zastosowaniem progów piętrzących. Eksploatowane są przede wszystkim wody pochodzące $\mathrm{z}$ wodonośnych utworów piętra czwartorzędowego, a w mniejszym stopniu z piętra karbońskiego. W ostatnich latach podaż wody ze wszystkich ujęć Jeleniej Góry kształtowała się na zbliżonym poziomie ok. 20 tys. $\mathrm{m}^{3} / \mathrm{d}$, w tym wody podziemne stanowiły poniżej $20 \%$. Zasoby eksploatacyjne wszystkich ujęć szacuje się na $39775 \mathrm{~m}^{3} / \mathrm{d}$ (Błachuta i in., 2016).

Do największych w regionie należą: ujęcie wód powierzchniowych zbiornika Sosnówka i ujęcie powierzchniowo-infiltracyjno-podziemne Grabarów. Oddane w 2002 r. ujęcie wód powierzchniowych zbiornika retencyjnego nr 11 Sosnówka (ryc. 1, tab. 1) jest pod względem możliwości poboru wody największym tego typu obiektem na terenie Kotliny Jeleniogórskiej. W ujęciu tym są pobierane wody powierzchniowe pochodzące w 70\% z rzeki Podgórnej, w 20\% z potoku Czerwonka i w $10 \%$ z potoku Sośniak (Błachuta i in., 2016). Maksymalna pojemność tego zbiornika, o powierzchni $145-175$ ha, wynosi $14 \mathrm{mln} \mathrm{m}^{3}$, a pojemność użytkowa $-8 \mathrm{mln} \mathrm{m}^{3}$. Zgodnie $\mathrm{z}$ pozwoleniem wodnoprawnym pobór wody może osiagać 25 tys. $\mathrm{m}^{3} / \mathrm{d}$ (Zawistowski, Michniewicz, 2009).

W ujęciu nr 6 Grabarów (ryc. 1, tab. 1) pobór wody wynosi 13,5 tys. $\mathrm{m}^{3} / \mathrm{d}$, co stanowi ok. $70 \%$ wszystkich wód ujmowanych przez ujęcia komunalne (Marszałek, Wąsik, 2012). Eksploatacja wód podziemnych, infiltracyjnych i powierzchniowych jest prowadzona za pomocą dwóch różnych i niezależnych od siebie systemów, w tym utwo-

Tab. 1. Charakterystyka wybranych ujęć wody z obszaru granitu karkonoskiego

Table 1. Characteristics of selected water intakes from the Karkonosze granite area

\begin{tabular}{|c|c|c|c|c|c|c|c|c|}
\hline $\begin{array}{l}\mathrm{Nr} \\
\text { No }\end{array}$ & $\begin{array}{l}\text { Typ i nazwa ujęcia } \\
\text { Type and name } \\
\text { of intake }\end{array}$ & $\begin{array}{c}\text { Ujęte wody } \\
\text { Captured waters }\end{array}$ & $\begin{array}{l}\text { Glówne obiekty } \\
\text { ujęcia } \\
\text { Main objects } \\
\text { of intake }\end{array}$ & $\begin{array}{l}Q_{s t} / Q_{z r} \\
{\left[\mathrm{~m}^{3} / \mathrm{h}\right]} \\
Q_{\text {ujecia }} \\
{\left[\mathrm{m}^{3} / \mathrm{d}\right]}\end{array}$ & $\begin{array}{c}s \\
{[\mathrm{~m}]}\end{array}$ & $\begin{array}{c}q \\
{\left[\mathbf{m}^{3} / \mathbf{h} \times \mathbf{m}\right]}\end{array}$ & $\begin{array}{c}k \\
{[\mathrm{~m} / \mathrm{d}]}\end{array}$ & $\begin{array}{c}\text { Wskaźniki } \\
\text { obniżające } \\
\text { jakość wody } \\
\text { Indicators } \\
\text { lowering water } \\
\text { quality }\end{array}$ \\
\hline $1 \mathrm{~A}-\mathrm{G}$ & $\begin{array}{l}\text { wód podziemnych } \\
\text { groundwater }\end{array}$ & $\begin{array}{l}\text { piętra karbońskiego } \\
\text { Carboniferous } \\
\text { multiaquifer formation }\end{array}$ & $\begin{array}{l}\text { studnie o gt. do } 100 \mathrm{~m} \\
\text { wells up to } 100 \mathrm{~m} \\
\text { deep }\end{array}$ & $\begin{array}{c}0,12-2,7 \\
-\end{array}$ & $\begin{array}{c}1,1-18 \\
-\end{array}$ & $0,01-0,5$ & $0,02-0,86$ & $\begin{array}{c}\mathrm{pH}, \dot{Z} \\
\text { niska twardość } \\
\text { pH, } \\
\text { low hardness }\end{array}$ \\
\hline $2 \mathrm{~A}-\mathrm{C}$ & $\begin{array}{l}\text { wód podziemnych } \\
\text { groundwater }\end{array}$ & $\begin{array}{l}\text { piętra karbońskiego } \\
\text { Carboniferous } \\
\text { multiaquifer formation }\end{array}$ & $\begin{array}{l}\text { studnie o gł. od } \\
\text { kilkuset do } 2 \text { tys. m } \\
\text { wells with several } \\
\text { hundreds m to } 2 \mathrm{~km} \\
\text { of depth }\end{array}$ & $\begin{array}{c}20,5-45 \\
-\end{array}$ & $\begin{array}{l}97 \\
-\end{array}$ & 0,21 & 0,29 & $\mathrm{~F}$ \\
\hline 3 & $\begin{array}{l}\text { wód podziemnych } \\
\text { Ceglana } \\
\text { (nieczynne) } \\
\text { groundwater } \\
\text { "Ceglana" } \\
\text { (inactive) }\end{array}$ & $\begin{array}{l}\text { piętra } \\
\text { czwartorzędowego } \\
\text { Quaternary } \\
\text { multiaquifer formation }\end{array}$ & $\begin{array}{l}3 \text { studnie wiercone } \\
5 \text { kopanych studni } \\
\text { szybowych } \\
3 \text { drilled and } \\
5 \text { dug wells }\end{array}$ & $\begin{array}{c}11,7-16,8 \\
2500\end{array}$ & $\begin{array}{c}1,5-1,9 \\
4,4\end{array}$ & $\begin{array}{c}6,4-11,2 \\
2,68\end{array}$ & $\begin{array}{c}46,9-65,0 \\
17,1\end{array}$ & $\begin{array}{c}\text { Fe, Mn, } \\
\text { bakterie, barwa, } \\
\text { mętność, } \\
\text { utlenialność } \\
\text { Fe, Mn, } \\
\text { bacteria, } \\
\text { colour, } \\
\text { turbidity, } \\
\text { oxidability } \\
\end{array}$ \\
\hline $4 \mathrm{~A}-\mathrm{C}$ & $\begin{array}{l}\text { wód podziemnych } \\
\text { groundwater }\end{array}$ & $\begin{array}{l}\text { piętra karbońskiego } \\
\text { Carboniferous } \\
\text { multiaquifer formation }\end{array}$ & $\begin{array}{l}\text { źródła } \\
\text { springs }\end{array}$ & $\begin{array}{c}0,1-5,1 \\
-\end{array}$ & - & $\begin{array}{l}- \\
- \\
-\end{array}$ & $\begin{array}{l}- \\
- \\
-\end{array}$ & $\begin{array}{c}\mathrm{pH}, \mathrm{Z} \\
\text { niska twardość } \\
\text { pH and } \\
\text { low hardness }\end{array}$ \\
\hline $5 \mathrm{~A}-\mathrm{C}$ & $\begin{array}{l}\text { wód podziemnych } \\
\text { groundwater }\end{array}$ & $\begin{array}{l}\text { piętra karbońskiego } \\
\text { Carboniferous } \\
\text { multiaquifer formation }\end{array}$ & $\begin{array}{l}\text { sztolnia, szyb } \\
\text { well, shaft }\end{array}$ & $\begin{array}{c}1-20 \\
- \\
\end{array}$ & $\begin{array}{l}- \\
-\end{array}$ & - & $\begin{array}{l}- \\
- \\
-\end{array}$ & $\mathrm{Rn}$ \\
\hline 6 & $\begin{array}{l}\text { infiltracyjne } \\
\text { Grabarów } \\
\text { infiltration } \\
\text { "Grabarów" }\end{array}$ & $\begin{array}{l}\text { rzeki Bóbr, } \\
\text { podziemne piętra } \\
\text { czwartorzędowego } \\
\text { the Bóbr River, } \\
\text { Quaternary } \\
\text { multiaquifer formation }\end{array}$ & $\begin{array}{l}\text { studnie szybowe, } \\
\text { stawy infiltracyjne, } \\
\text { studnie drenażowe } \\
\text { dug wells, } \\
\text { infiltration ponds, } \\
\text { drainage wells }\end{array}$ & $\begin{array}{l}30-80 \\
13500\end{array}$ & $\begin{array}{l}3,3-4,1 \\
1,6-2,9\end{array}$ & $\begin{array}{c}8,3-23,5 \\
16,4-64,6\end{array}$ & $\begin{array}{l}22,5-63,4 \\
86,4-414,7\end{array}$ & $\mathrm{Fe}$ \\
\hline
\end{tabular}

Objaśnienia / Eksplanations: $\boldsymbol{Q}_{\mathrm{st}}$ - wydajność studni / well discharge; $\boldsymbol{Q}_{\mathbf{i r}}-$ wydajność źródła / spring discharge; $\boldsymbol{Q}_{\text {ujecia }}-$ wydajność ujęcia / intake discharge; $\boldsymbol{s}$-depresja / depression; $\boldsymbol{q}$-wydatek jednostkowy / specific discharge; $\boldsymbol{k}$ - współczynnik filtracji / hydraulic conductivity 
Ciąg dalszy tab. 1. Charakterystyka wybranych ujęć wody z obszaru granitu karkonoskiego

Continuation of table 1. Characteristics of selected water intakes from the Karkonosze granite area

\begin{tabular}{|c|c|c|c|c|c|c|c|c|}
\hline $\begin{array}{l}\mathrm{Nr} \\
\text { No }\end{array}$ & $\begin{array}{l}\text { Typ i nazwa ujęcia } \\
\text { Type and name } \\
\text { of intake }\end{array}$ & $\begin{array}{c}\text { Ujęte wody } \\
\text { Captured waters }\end{array}$ & $\begin{array}{l}\text { Główne obiekty } \\
\text { ujęcia } \\
\text { Main objects } \\
\text { of intake }\end{array}$ & $\begin{array}{l}Q_{s t} / Q_{i r} \\
{\left[\mathrm{~m}^{3} / \mathrm{h}\right]} \\
Q_{\text {ujecia }} \\
{\left[\mathrm{m}^{3} / \mathrm{d}\right]}\end{array}$ & $\begin{array}{c}s \\
{[\mathrm{~m}]}\end{array}$ & $\begin{array}{c}q \\
{\left[\mathbf{m}^{3} / \mathbf{h} \times \mathbf{m}\right]}\end{array}$ & $\begin{array}{c}k \\
{[\mathbf{m} / \mathbf{d}]}\end{array}$ & $\begin{array}{c}\text { Wskaźniki } \\
\text { obniżające } \\
\text { jakość wody } \\
\text { Indicators } \\
\text { lowering water } \\
\text { quality }\end{array}$ \\
\hline 7 & $\begin{array}{l}\text { powierzchniowo- } \\
\text {-drenażowe } \\
\text { Huta Julia } \\
\text { surface-drainage } \\
\text { "Huta Julia" }\end{array}$ & $\begin{array}{l}\text { potoku bez nazwy } \\
\text { i wód piętra } \\
\text { karbońskiego } \\
\text { unnamed stream } \\
\text { and groundwater } \\
\text { of Carboniferous } \\
\text { multiaquifer formation }\end{array}$ & $\begin{array}{l}\text { zbiornik ujściowy, } \\
\text { rura poborowa, } \\
2 \text { studnie ujęciowe } \\
\text { outlet reservoir, } \\
\text { intake pipe, } \\
2 \text { intake wells }\end{array}$ & $\stackrel{-}{200}$ & - & - & - & \\
\hline 8 & $\begin{array}{l}\text { powierzchniowo- } \\
\text {-drenażowe } \\
\text { Ślquski Dom } \\
\text { surface-drainage } \\
\text { "Ślaski Dom" }\end{array}$ & $\begin{array}{l}\text { Złotego Potoku, } \\
\text { podziemne piętra } \\
\text { czwartorzędowego } \\
\text { i karbońskiego } \\
\text { the Zloty Potok River, } \\
\text { groundwater } \\
\text { of Quaternary } \\
\text { and Carboniferous } \\
\text { multiaquifer formation }\end{array}$ & $\begin{array}{l}\text { zbiornik ujęciowy, } \\
\text { rura poborowa; } \\
\text { obudowane źródło } \\
\text { intake reservoir, } \\
\text { intake pipe, } \\
\text { encased spring }\end{array}$ & $\begin{array}{c}34 \\
1522\end{array}$ & - & $\begin{array}{l}- \\
-\end{array}$ & $\begin{array}{l}- \\
-\end{array}$ & $\begin{array}{l}\text { niska twardość, } \\
\text { pH, barwa, } \\
\text { BZT5, związki } \\
\text { organiczne, } \\
\text { bakterie } \\
\text { low hardness, } \\
\text { pH, colour, } \\
\text { BZT5, organic } \\
\text { compunds, } \\
\text { bacteria }\end{array}$ \\
\hline 9 & $\begin{array}{l}\text { powierzchniowo- } \\
\text {-drenażowe } \\
\text { Wilcza I } \\
\text { surface-drainage } \\
\text { "Wilcza I" }\end{array}$ & $\begin{array}{l}\text { rzeki Łomnica, } \\
\text { podziemne piętra } \\
\text { czwartorzędowego } \\
\text { i karbońskiego } \\
\text { the Łomnica River, } \\
\text { groundwater of } \\
\text { Quaternary and } \\
\text { Carboniferous } \\
\text { multiaquifer formation }\end{array}$ & $\begin{array}{l}\text { zbiornik ujściowy, } \\
\text { rura poborowa, } \\
\text { ciagi drenażowe } \\
\text { outlet reservoir, } \\
\text { intake pipe, } \\
\text { drainage lines }\end{array}$ & $\begin{array}{c}- \\
1100\end{array}$ & $\begin{array}{l}- \\
-\end{array}$ & $\begin{array}{l}- \\
-\end{array}$ & $\begin{array}{l}- \\
-\end{array}$ & \\
\hline 10 & $\begin{array}{l}\text { powierzchniowo- } \\
\text {-drenażowe } \\
\text { Wilcza Poręba II } \\
\text { surface-drainage } \\
\text { "Wilcza Poręba II" }\end{array}$ & $\begin{array}{l}\text { rzeki Czerniawka, } \\
\text { podziemne piętra } \\
\text { czwartorzedowego } \\
\text { i karbońskiego } \\
\text { the Czerniawka River, } \\
\text { groundwater } \\
\text { of Quaternary } \\
\text { and Carboniferous } \\
\text { multiaquifer formation }\end{array}$ & $\begin{array}{l}\text { zbiornik ujęciowy, } \\
\text { rura poborowa, } \\
\text { ciagi drenażowe } \\
\text { intake reservoir, } \\
\text { intake pipe, } \\
\text { drainage lines }\end{array}$ & $\begin{array}{c}- \\
300\end{array}$ & - & $\begin{array}{l}- \\
-\end{array}$ & - & \\
\hline 11 & $\begin{array}{l}\text { wód } \\
\text { powierzchniowych } \\
\text { Sosnówka } \\
\text { surface water } \\
\text { "Sosnówka" }\end{array}$ & $\begin{array}{l}\text { potoków Czerwonka, } \\
\text { Sośniak i Podgórna } \\
\text { the Czerwonka, } \\
\text { Sośniak } \\
\text { and Podgórna Rivers }\end{array}$ & $\begin{array}{l}\text { zbiornik o pow. } 175 \text { ha } \\
\text { i objętości } 8 \mathrm{mln} \mathrm{m}^{3} \\
\text { reservoir with an } \\
\text { area of } 175 \text { ha and } \\
8 \mathrm{mln} \mathrm{m}^{3} \text { of volume }\end{array}$ & 25000 & - & - & $\begin{array}{l}- \\
-\end{array}$ & $\mathrm{pH}, \mathrm{Mn}, \mathrm{Fe}$ \\
\hline 12 & $\begin{array}{l}\text { wód } \\
\text { powierzchniowych } \\
\text { Kamieńczyk } \\
\text { surface water } \\
\text { "Kamieńczyk" }\end{array}$ & $\begin{array}{l}\text { potoku Kamieńczyk } \\
\text { the Kamieńczyk River }\end{array}$ & $\begin{array}{l}\text { zbiornik ujęciowy, } \\
\text { studnia ujęiowa } \\
\text { intake reservoir } \\
\text { and well }\end{array}$ & $\begin{array}{c}- \\
590\end{array}$ & $\begin{array}{l}- \\
-\end{array}$ & $\begin{array}{l}- \\
-\end{array}$ & - & $\begin{array}{l}\text { barwa, } \mathrm{pH}, \\
\text { utlenialność } \\
\text { colour, } \mathrm{pH}, \\
\text { oxidability }\end{array}$ \\
\hline 13 & $\begin{array}{l}\text { wód } \\
\text { powierzchniowych } \\
\text { Kamienna Wieża } \\
\text { surface water } \\
\text { "Kamienna Wieża" }\end{array}$ & $\begin{array}{l}\text { Polskiego Potoku } \\
\text { the Polski Potok River }\end{array}$ & $\begin{array}{l}\text { zbiornik ujęciowy, } \\
\text { studnia ujęciowa } \\
\text { intake reservoir } \\
\text { and well }\end{array}$ & $\begin{array}{c}- \\
320\end{array}$ & - & $\begin{array}{l}- \\
-\end{array}$ & $\begin{array}{l}- \\
-\end{array}$ & $\begin{array}{l}\text { barwa, } \mathrm{pH}, \\
\text { utlenialność } \\
\text { colour, pH, } \\
\text { oxidability }\end{array}$ \\
\hline 14 & $\begin{array}{l}\text { wód } \\
\text { powierzchniowych } \\
\text { Leśniczówka } \\
\text { surface water } \\
\text { "Leśniczówka" }\end{array}$ & $\begin{array}{l}\text { potoku Sopot } \\
\text { the Sopot River }\end{array}$ & $\begin{array}{l}\text { zbiornik ujęciowy, } \\
\text { studnia ujęciowa } \\
\text { intake reservoir } \\
\text { and well }\end{array}$ & $\begin{array}{c}- \\
675\end{array}$ & $\begin{array}{l}- \\
-\end{array}$ & $\begin{array}{l}- \\
-\end{array}$ & $\begin{array}{l}- \\
-\end{array}$ & $\begin{array}{l}\text { barwa, } \mathrm{pH}, \\
\text { utlenialność } \\
\text { colour, } \mathrm{pH}, \\
\text { oxidability }\end{array}$ \\
\hline
\end{tabular}

Objaśnienia / Eksplanations: $\boldsymbol{Q}_{\text {st }}$ - wydajność studni / well discharge; $\boldsymbol{Q}_{\text {ir }}$ - wydajność źródła / spring discharge; $\boldsymbol{Q}_{\text {ujecia }}-$ wydajność ujęcia / intake discharge; $\boldsymbol{s}$ - depresja / depression; $\boldsymbol{q}$ - wydatek jednostkowy / specific discharge; $\boldsymbol{k}$ - współczynnik filtracji / hydraulic conductivity

rzonego na początku lat 70. jednostopniowego systemu pierwotnego, bazującego na zespole studni szybowych usytuowanych wzdłuż lewego brzegu Bobru. Studniami szybowymi pobiera się wody pochodzące $\mathrm{z}$ infiltracji brzegowej (naturalnej) oraz z dopływu podziemnego, w ilości $610 \mathrm{~m}^{3} / \mathrm{h} .92 \%\left(561,2 \mathrm{~m}^{3} / \mathrm{h}\right)$ tego poboru przypada na infiltrację brzegową wód Bobru, natomiast udział wód ujmowanych $\mathrm{z}$ dopływu podziemnego wynosi zaledwie 8\%
(Marszałek, Wąsik, 2012). Drugim systemem ujęcia Grabarów jest wykonany w latach 80 . ubiegłego wieku system dwustopniowy. Pierwszy stopień polega na poborze wód rzeki Bóbr przez ujęcie brzegowe Wojanów i na przesyłaniu ich grawitacyjnie rurociagiem do dziewięciu stawów infiltracyjnych ujęcia Grabarów, natomiast drugi stopień polega na drenażu pionowo-poziomym z zastosowaniem studni wierconych i drenażowych, ujmujących wodę infiltrującą 
z tych stawów. Studnie wiercone i drenażowe tego nowszego systemu są rozmieszczone w dwóch równoległych do siebie szeregach w bezpośrednim otoczeniu kompleksu stawów infiltracyjnych.

W rejonie Kotliny Jeleniogórskiej i Karkonoszy występuje również wiele mniejszych ujęć wód powierzchniowych, m.in.: Kamienna Wieża na Polskim Potoku, Leśniczówka na potoku Sopot, Biały Potok powyżej Karpacza, oraz ujęcia na rzekach Podgórna w Podgórzynie, Mała Kamienna w Górzyńcu, Kamieńczyk, Ciekotka i Szrenicki Potok (ujęcia: Na stoku Szrenicy i Łabski Szczyt), Szlifierska Struga (ujęcie Biała Dolina), a także na ciekach bez nazwy (ujęcia: Jutrzenka i Polanka).

Ujęcie nr 14 - Leśniczówka na potoku Sopot (ryc. 1, tab. 1) ma największą wydajność spośród trzech górskich ujęć wód powierzchniowych zlokalizowanych w Jagniątkowie, administracyjnie należącym do Jeleniej Góry, jednak geograficznie do Karkonoszy. Ujęcie zaopatruje w wodę przede wszystkim Jagniątków oraz część Sobieszowa, stanowiącego dzielnicę Jeleniej Góry. Pozwolenie wodnoprawne zezwala na pobór $90 \mathrm{~m}^{3} / \mathrm{h}$ wód powierzchniowych, $\mathrm{z}$ zaleceniem zachowania $\mathrm{w}$ potoku Sopot poniżej stopnia piętrzącego wody ujęcia $0,057 \mathrm{~m}^{3} / \mathrm{s}$ przepływu nienaruszalnego. W 2014 r. pobór wody wyniósł $0,246 \mathrm{mln}^{3}$, co stanowiło $4 \%$ sumarycznego poboru wody dla Jeleniej Góry.

Ujęcie nr 13 - Kamienna Wieża (ryc. 1, tab. 1) dla potrzeb Jagniątkowa ujmuje na terenie Karkonoskiego Parku Narodowego wody powierzchniowe Polskiego Potoku. Aktualne pozwolenie wodnoprawne zezwala na pobór wód powierzchniowych w ilości $700 \mathrm{~m}^{3} / \mathrm{d}$, przy zachowaniu przepływu nienaruszalnego $2,70 \mathrm{dm}^{3} / \mathrm{s}$. W 2014 r. pobór wody $\mathrm{z}$ tego ujęcia wyniósł $0,118 \mathrm{mln} \mathrm{m}^{3}$, co stanowiło zaledwie $2 \%$ sumarycznego poboru wody dla Jeleniej Góry.

Wydajność pozostałych wymienionych ujęć wód powierzchniowych jest zróżnicowana - wynosi od kilkudziesięciu do kilkuset $\mathrm{m}^{3} / \mathrm{d}\left(\right.$ Polanka $-60 \mathrm{~m}^{3} / \mathrm{d}$; Kamień$\left.c z y k-590 \mathrm{~m}^{3} / \mathrm{d}\right)$.

Odrębną grupę stanowią ujęcia drenażowe, liczne na opisywanym obszarze, lub drenażowo-powierzchniowe. Ujęcia drenażowe ujmują wody podziemne występujące płytko pod powierzchnią terenu, głównie w pokrywach zwietrzelinowych. W górnych partiach zachodniej części Karkonoszy ujęcie drenażowe zaopatrujące schronisko na Hali Szrenickiej ma średnią wydajność $17,3 \mathrm{~m}^{3} / \mathrm{d}$, natomiast grupa ujęć drenażowo-powierzchniowych nr 7 Huta Julia (ryc. 1, tab. 1) w Szklarskiej Porębie - ponad $200 \mathrm{~m}^{3} / \mathrm{d}$. W ujęciu tym są pobierane wody powierzchniowe bezimiennego potoku oraz wody podziemne strefy przypowierzchniowej.

W górnej części zlewni Łomnicy funkcjonują ujęcia powierzchnio-drenażowe służące do zaopatrzenia w wodę pitną miasta Karpacz. Ujęcie Wielki Staw składa się z ujęcia wód powierzchniowych Kozi Mostek na Białym Potoku oraz ujęcia wód podziemnych Wielki Staw, czerpiącego wodę z utworów czwartorzędowych (Juda, 2000; Krukowski, 2010). Łączna wydajność całego ujęcia wynosi $831,2 \mathrm{~m}^{3} / \mathrm{d}$, z czego na ujęcie Kozi Mostek przypada $207,2 \mathrm{~m}^{3} / \mathrm{d}$, a na ujęcie Wielki Staw $624 \mathrm{~m}^{3} / \mathrm{d}$ (Juda, 2000). Zgodnie z pozwoleniem wodnoprawnym średni pobór wody z ujęcia Wielki Staw wynosi $621 \mathrm{~m}^{3} / \mathrm{d}$.
Ujęcie Mały Staw składa się z ujęcia powierzchniowego na Łomnicy (w $18 \mathrm{~km}$ jej biegu) oraz 8 studni drenażowych w rejonie Małego i Wielkiego Stawu. Wydajność ujęcia wód podziemnych określono na $864 \mathrm{~m}^{3} / \mathrm{d}$, natomiast ujęcia wód powierzchniowych na $630,7 \mathrm{~m}^{3} / \mathrm{d}$ (Kluczyński, 2011). Wydane pozwolenie wodnoprawne zezwala na korzystanie z wód ujęcia Mały Staw w maksymalnej ilości do $621 \mathrm{~m}^{3} / \mathrm{d}$ i średniej wydajności równej $423 \mathrm{~m}^{3} / \mathrm{d}$. Inne ujęcia powierzchnio-drenażowe Karpacza - Ślaski Dom, Wilcza I oraz Wilcza Poręba II (kolejno nr 8, 9 i 10, ryc. 1, tab. 1) - pracują z wydajnością od 300 do $1522 \mathrm{~m}^{3} / \mathrm{d}$.

Ujęcie Śnieżne Kotty, zlokalizowane w zlewni Wrzosówki, zaopatruje w wodę pitną mieszkańców Michałowic i część Jagniątkowa. Średni pobór wody z tego ujęcia wynosi $254 \mathrm{~m}^{3} / \mathrm{d}$.

Jednym z większych ujęć wód podziemnych na opisywanym obszarze jest, należące do Agencji Mienia Wojskowego, ujęcie przy ul. Podchorążych w Jeleniej Górze, z zasobami $1080 \mathrm{~m}^{3} / \mathrm{d}$, oraz ujęcie w Jeżowie Sudeckim o zasobach $1750 \mathrm{~m}^{3} / \mathrm{d}$. Ujęcie nr 3 Ceglana (ryc. 1, tab. 1) w Jeleniej Górze (obecnie nieeksploatowane) zaspokajało ok. 4\% całkowitego zapotrzebowania miasta na wodę. Zasoby tego ujęcia, składającego się z 5 studni szybowych i 3 wierconych, określono na 2,5 tys. $\mathrm{m}^{3} / \mathrm{d}$. Wydajność eksploatacyjna poszczególnych studni tego ujęcia wynosi od 11,7 do $16,8 \mathrm{~m}^{3} / \mathrm{h}$. Studnie te ujmują wody czwartorzędowego piętra wodonośnego. Pozostałe ujęcia wód masywu krystalicznego, zwykle 1-2 otworowe, zaopatrują poszczególne obiekty przemysłowe, użyteczności publicznej i prywatne posesje. Ich wydajność mieści się zwykle w przedziale od 0,2 do $2,7 \mathrm{~m}^{3} / \mathrm{h}$ (tab. 1 ).

W Cieplicach Śląskich-Zdroju na terenie Jeleniej Góry, eksploatuje się słabo zmineralizowane $\left(600-850 \mathrm{mg} / \mathrm{dm}^{3}\right)$ lecznicze wody termalne, osiagające na wypływie temperaturę ok. $87^{\circ} \mathrm{C}$ w otworze $\mathrm{nr} 2 \mathrm{~A}$ (ryc. 1, tab. 1). Wody termalne są również ujmowane otworami nr 2B w Staniszowie i 2C w Karpnikach. Wszystkie są związane ze strefami dyslokacyjnymi w granicie karkonoskim (ryc. 1). Ich zasoby eksploatacyjne wynoszą od 20,5 do $45 \mathrm{~m}^{3} / \mathrm{h}$ (tab. 1) (Liber-Makowska, Łukaczyński, 2016).

$\mathrm{Na}$ obszarze granitowego masywu Karkonoszy stosunkowo często są ujmowane wody źródeł. Ze względu na niską wydajność (często poniżej $0,5 \mathrm{dm}^{3} / \mathrm{s}$ ) służą one do zaopatrzenia w wodę pojedynczych gospodarstw lub ośrodków wczasowych, najzasobniejsze z nich osiagają wydajność ponad $5 \mathrm{dm}^{3} / \mathrm{s}$. Warto również wspomnieć o wypływach ze sztolni, które są liczne na analizowanym obszarze. Niektóre z nich, o wydajności od 1 do $20 \mathrm{~m}^{3} / \mathrm{h}$, są wykorzystywane do zaopatrzenia lokalnych gospodarstw, a nawet mniejszych miejscowości.

\section{DYSKUSJA}

Analiza warunków hydrogeologicznych karkonoskiego masywu granitowego i przegląd ujęć wód funkcjonujących na jego obszarze wskazują na utrudnienia w budowie dużego ujęcia wód podziemnych, które pokryłoby zapotrzebowanie na wodę miasta średniej wielkości. Większą wydajność można uzyskać instalując ujęcia wód powierzchniowych oraz ujęcia drenażowe, zlokalizowane w sąsiedztwie dużej rzeki. W przypadku tego typu ujęć problemów przysparza nieodpowiednia jakość wód powierzchniowych, które w opisywanym regionie należą 
do III klasy jakości, a niektóre wskaźniki, np. zawartość bakterii grupy coli i bakterii coli typu kałowego, świadczą o IV czy V klasie czystości.

$\mathrm{Na}$ obszarach pozbawionych większych cieków pewnym rozwiązaniem jest budowa ujęcia bazującego na wodach powierzchniowych kilku mniejszych cieków. Przykładem jest Sosnówka, największe ujęcie zaopatrujące w wodę Jelenią Górę. Korzystanie z niego nie odbywa się jednak bezproblemowo. W okresach suchych zasilanie przez mniejsze potoki jest bardzo mocno ograniczone, co poza zmniejszeniem możliwych do wykorzystania zasobów skutkuje również pogorszeniem jakości wody. Pojawiają się zakwity glonów, spada natlenienie wody w zbiorniku oraz w cieku poniżej niego. Odczyn wody w zbiorniku oraz zawartość w niej Fe i Mn przekraczają normę dla wód pitnych.

Ujęcia powierzchniowo-drenażowe są powszechne na badanym obszarze, szczególnie w jego górskiej części. Charakteryzują się one zróżnicowaną wydajnością - od kilkuset do dwóch tysięcy $\mathrm{m}^{3} / \mathrm{d}$. Z ujęć tego typu, ujmujących wody małych potoków oraz wody podziemne występujące do głębokości kilku metrów, korzystają głównie miejscowości Karpacz, Szklarska Poręba i Kowary. Mankamentem tego typu ujęć jest ich niestabilna wydajność, w dużym stopniu uzależniona od zasilania atmosferycznego. W ostatnich latach wydajność tego typu ujęć znacznie spadła. W okresach suchych bywają one wyłączane ze względu na brak wody, a jakość ujmowanych wód wymusza konieczność ich uzdatniania.

Określony w połowie lat 80 . schemat występowania rocznych opadów w klimatycznym subregionie karkonosko-izerskim, wykazujący dwa wyraźne maksima: główny w miesiącach letnich i niewiele niższy w miesiącach jesienno-zimowych (Kwiatkowski, Hołdys, 1985), ulega w ostatnich latach znacznym zmianom. Coraz częściej obserwuje się głębokie niżówki zarówno w okresie letnim, jak i w zimowym. Z powodu nasilającego się ruchu turystycznego, generującego wzmożone zapotrzebowanie na wodę, często dochodzi do nadmiernej eksploatacji ujęć i poboru znacznie przekraczającego wielkości ustalone w pozwoleniach wodnoprawnych. Skutki takiego postępowania obserwowano koło ujęcia Wielki Staw, gdzie w okolicy Koziego Mostku dochodziło nawet do całkowitego wyschnięcia Białego Potoku (ryc. 3). Istniejące tam ujęcie wody powierzchniowej, należące do zespołu ujęć Wielki Staw, w okresach wzmożonego zapotrzebowania i niskich stanów wód pobiera prawie cały przepływ wody w potoku. Nie są więc respektowane ograniczenia poboru wody w zakresie zachowania przepływu nienaruszalnego, nie mówiąc już o przepływie biologicznym. W roku hydrolo- gicznym 2015, ze względu na ciągły pobór wody przy długotrwałym braku opadów atmosferycznych, przez ok. 170 dni potok w dolnej części poniżej ujęcia był suchy.

Na obszarze krystalicznego masywu Karkonoszy wody podziemne są pobierane $\mathrm{z}$ utworów czwartorzędowych oraz karbońskich, ale tylko w tych pierwszych występują główne użytkowe poziomy wodonośne, najbardziej perspektywiczne do lokalizacji ujęć wód podziemnych (Kiełczawa, Czerski, 1997; Marszałek, Wąsik, 2002). Wyniki badań modelowych, wykonanych na obszarze Kotliny Jeleniogórskiej, wykazały możliwość budowy kilkuotworowych ujęć o wydajności 2-3,5 tys. $\mathrm{m}^{3} / \mathrm{d}$ na obszarach o większym nagromadzeniu osadów czwartorzędowych (Marszałek, Wąsik, 2012).

Rozwiązaniem dla mniejszych osad oraz pojedynczych gospodarstw, rozproszonych na obszarze masywu karkonoskiego, są ujęcia jedno-, dwuotworowe o głębokości do

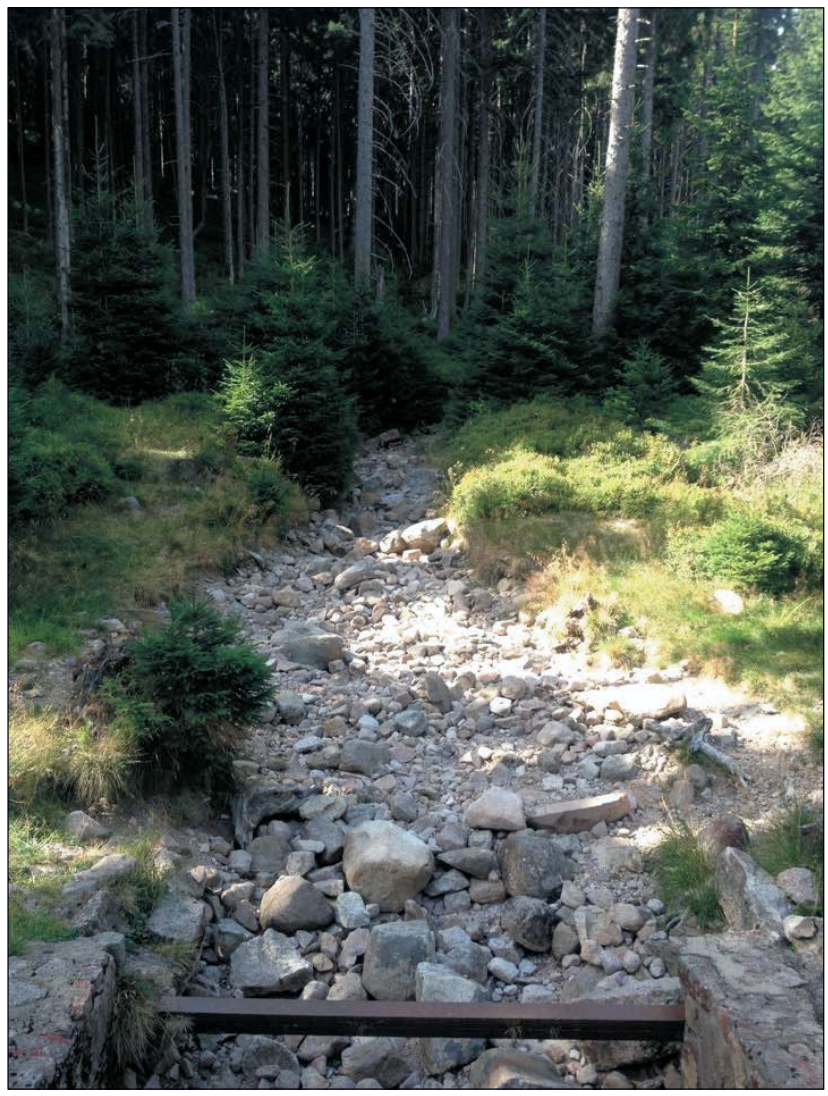

Ryc. 3. Biały Potok w okolicach Koziego Mostku - poniżej ujęcia wód powierzchniowych Wielki Staw (stan w dniu 27.08.2015 r.)

Fig. 3. Biały Potok stream near Kozi Mostek - downstream of the water intake Wielki Staw (as of 27.08.2015)

Tab. 2. Wyniki testów hydrogeologicznych przeprowadzonych w otworach badawczych wywierconych w granitach karkonoskich Table 2. Results of hydrogeological tests carried out in boreholes drilled in the Karkonosze granites

\begin{tabular}{|l|c|c|c|c|c|c|}
\hline $\begin{array}{c}\text { Nr otworu } \\
\text { Borehole } \\
\text { No }\end{array}$ & $\begin{array}{c}\text { Glębokość otworu } \\
\text { Borehole depth }\end{array}$ & $\begin{array}{c}\text { Wydajność } \\
\text { Discharge rate } \\
{\left[\mathbf{m}^{3} / \mathbf{h}\right]}\end{array}$ & $\begin{array}{c}\text { Depresja } \\
\text { Depression } \\
{[\mathbf{m}]}\end{array}$ & $\begin{array}{c}\text { Wydatek } \\
\text { jednostkowy } \\
\text { Specific discharge } \\
{\left[\mathbf{m}^{\mathbf{3}} \mathbf{/ h} \times \mathbf{m}\right]}\end{array}$ & $\begin{array}{c}\text { Przewodność } \\
\text { Transmissivity } \\
{\left[\mathbf{m}^{2} / \mathbf{d}\right]}\end{array}$ & $\begin{array}{c}\text { Wspótczynnik filtracji } \\
\text { Hydraulic conductivity } \\
{[\mathbf{m} / \mathbf{d}]}\end{array}$ \\
\hline 1A & 17,6 & 0,25 & 2,75 & 0,09 & 0,85 & 0,22 \\
\hline 1B & 6,7 & 0,13 & 1,11 & 0,12 & 1,2 & 0,28 \\
\hline 1C & 12,6 & 0,12 & 2,92 & 0,04 & 0,92 & 0,12 \\
\hline
\end{tabular}


60-100 m, ujmujące wody szczelinowe karbońskiego masywu granitowego. Wydajność takich ujęć wynosi najczęściej od poniżej 1 do kilku $\mathrm{m}^{3} / \mathrm{h}$ (tab. 1,2). O ich większej wydajności decyduje lokalizacja studni w strefie silniej zaangażowanej tektonicznie, charakteryzującej się większą gęstością spękań. Chociaż ujęcia te nie należą do bardzo wydajnych, to jednak charakteryzują się większą stabilnością wydajności i składu chemicznego wód.

Należy również wspomnieć o głębokich otworach, ujmujących wody z głębokości od kilkuset do 2000 m p.p.t., które do tej pory były wykonywane w celu ujęcia wód termalnych, wykorzystywanych jako źródło energii cieplnej oraz w balneologii. Ostatnio coraz częściej zaczynają pojawiać się rozwiązania, w których jednym ze sposobów kaskadowego wykorzystania tych wód ma być cel konsumpcyjny. Uwzględniając wydajność eksploatacyjną dotychczas wykonanych głębokich otworów, rozwiązania te wydają się realne.

Ważnym typem ujęć, popularnym szczególnie na obszarach górskich, są ujęcia źródeł. Ich wydajność gwarantuje zaopatrzenie w wodę o stosunkowo dobrej jakości pojedynczych gospodarstw domowych (a czasem nawet kilku).

Ciekawym i zarazem kuszącym rozwiązaniem są próby ujęć wód kopalnianych, wypływających sztolniami i szybami nieczynnych, zalanych kopaln. Głównym powodem realizacji takich przedsięwzięć jest zwykle ich względnie wysoka wydajność, sięgająca nawet kilkudziesięciu $\mathrm{dm}^{3} / \mathrm{s}$. Niestety, często zła jakość tych wód wyklucza możliwość ich wykorzystania. W opisywanym regionie funkcjonuje kilka tego typu ujęć (np. w Janowicach Wielkich), których wody, po prostym uzdatnieniu, są kierowane do odbiorców.

\section{PODSUMOWANIE}

O wielkości zasobów wodnych krystalicznego masywu Karkonoszy decyduje głównie stopień spękania skał zbiornikowych i wielkość opadów atmosferycznych zasilających wody sieci rzecznej oraz zbiorniki wód podziemnych. Zasoby te maleją wraz obniżeniem wielkości zasilania infiltracyjnego, szczególnie w okresach długotrwałych susz, które powodują drastyczne spadki objętości przepływu wód powierzchniowych, niekiedy doprowadzając do prawie całkowitego wyschnięcia mniejszych potoków oraz silnego zmniejszenia natężenia przepływu większych rzek. Naturalny reżim cieków powierzchniowych zostaje wtedy wyraźnie naruszony, a możliwość ujmowania z nich wód do celów zaopatrzenia w wodę jest ograniczona.

Ujęciami wód podziemnych, gwarantującymi zarówno stabilność wydajności, jak i stosunkowo dobrąjakość wód, są studnie wiercone o głębokości minimum kilkudziesięciu metrów. Ich liczba i rozkład powinny być dostosowane do wielkości zapotrzebowania oraz lokalnych warunków hydrogeologicznych.

\section{LITERATURA}

BŁACHUTA J., KONOWSKI R., MARSZAŁEK H., POPRAWSKI L., RYSIUKIEWICZ M., WAૃSIK M. 2016 - Koncepcja zaopatrzenia w wodę Miasta Jelenia Góra. Arch. Fundacji dla Uniwersytetu Wrocławskiego, Wrocław .

JANICKI B., KRAWCZYK J., KRYZA J., NOWACKI F. 1994 - Bilans wodno-gospodarczy wraz ze sformułowaniem warunków korzystania z wód zlewni rzeki Bóbr do przekroju powyżej zbiornika Pilchowice w zakresie wód podziemnych na podstawie dotychczasowych wyników badań na tym obszarze. Arch. PG Proxima, Wrocław.

JUDA W. 2000 - Operat wodnoprawny na pobór wód z zespołu ujęć Wielki Staw dla potrzeb miejskiej sieci wodociaggowej w Karpaczu. Arch. Biura Projektowego SYNTECH, Jelenia Góra.

KIEŁCZAWA J., CZERSKI M. 1997 - Mapa hydrogeologiczna Polski w skali 1:50 000, ark. Jelenia Góra. Państw. Inst. Geol., Warszawa.

KLECZKOWSKI A.S. (red.) 1990 - Mapa obszarów Głównych Zbiorników Wód Podziemnych (GZWP) w Polsce wymagających szczególnej ochrony 1:500 000. Wyd. IHiGI AGH, Kraków.

KLUCZYŃSKI H. 2011 - Operat wodnoprawny na pobór wody z ujęcia Mały Staw. Arch. Biura Projektów i Konsultingu PROJEKT s.c., Jelenia Góra.

KOWALSKI S. 1992 - Czynniki naturalne warunkujące występowanie wód podziemnych w regionie sudeckim. Acta Univ. Wratisl., 1324, Prace Geol.-Miner. XXV, Wrocław.

KOZDRÓJ W., KRENTZ O., OPLETAL M. 2001 - Mapa geologiczna Lausitz-Jizera-Karkonosze (bez osadów kenozoicznych) w skali 1:100000, Państw. Inst. Geol., Warszawa.

KRUKOWSKI R. 2010 - Dokumentacja hydrogeologiczna ustalająca zasoby eksploatacyjne ujęcia wód podziemnych Wielki Staw z utworów czwartorzędowych w Karpaczu. Arch. ZUGiI HYDROB, Jeżów Sudecki. KWIATKOWSKI J., HOŁDYS T. 1985 - Klimat. [W:] Jahn A. (red.), Karkonosze polskie. Ossolineum, Wrocław.

LIBER-MAKOWSKA E., ŁUKACZYŃSKI I. 2016 - Charakterystyka nowo rozpoznanego złoża wód termalnych w Karpnikach na tle warunków geotermicznych Kotliny Jeleniogórskiej. Tech. Posz. Geol. Geotermia, Zrównoważony Rozwój, 2: 5-16.

MARSZAŁEK H. 2007 - Kształtowanie zasobów wód podziemnych w rejonie Kotliny Jeleniogórskiej. Acta Univ. Wratisl., 2993, Hydrogeologia. Wyd. Uniw. Wroc., Wrocław.

MARSZAŁEK H., WĄSIK M. 2002 - Mapa hydrogeologiczna Polski w skali 1:50 000, ark. Wojcieszów. Państw. Inst. Geol., Warszawa.

MARSZAŁEK H., WĄSIK M. 2005 - Wodonośność skał krystalicznych metamorfiku kaczawskiego i izerskiego na podstawie wyników próbnych pompowań. [W:] Współczesne Problemy Hydrogelogii, tom XII, Wyd. UMK, Toruń: 491-497.

MARSZAŁEK H., WAૃSIK M. 2012 - Ocena możliwości ujęcia czwartorzędowego piętra wodonośnego w rejonie Kotliny Jeleniogórskiej. Biul. Państw. Inst. Geol., 451: 169-176.

MARSZAŁEK H., WĄSIK M., KUDŁACIK J. 2008 - Ocena zasobów eksploatacyjnych ujęcia wody Grabarów w Jeleniej Górze. Biul. Państw. Inst. Geol., 431: 145-152.

MIĘTUS M., ŁYSIAK-PASTUSZAK E., ZALEWSKA T., KRZEMIŃSKI W. (red.) 2011 - Projekt KLIMAT, Wpływ zmian klimatu na środowisko, gospodarkę i społeczeństwo, zad.1 Zmiany klimatu i ich wpływ na środowisko naturalne Polski oraz określenie ich skutków ekonomicznych. IMGW, Warszawa-Gdynia-Kraków.

STAŚKO S., TARKA R. 2002 - Zasilanie i drenaż wód podziemnych w obszarach górskich na podstawie badań w Masywie Śnieżnika. Acta Univ. Wratisl., 2528, Hydrogeologia, Wrocław.

STAŚKO S., WOJTKOWIAK A. 2004 - Występowanie i jakość wód podziemnych w skałach krystalicznych Sudetów na podstawie badań ujeć. Prz. Geol., 52 (1): 69-75.

STAŚKO S., OLICHWER T., TARKA R. 2008 - Susza hydrogeologiczna w Sudetach. Materiały konferencyjne, XII Międzynarodowa Konferencja Naukowo-Techniczna Zarzadzanie zasobami wodnymi w dorzeczu Odry, 11-14.05.2008 r., Szklarska Poręba: 37-46.

ZALESKA M., ŚLIWKA R., KUDŁACIK J., HAŁADAJ J. 1999 Dokumentacja hydrogeologiczna regionu sudeckiego - zlewnie górnych biegów Nysy Łużyckiej i Bobru wraz z oceną zasobów poziomów wodonośnych. Arch. Arcadis Ekokonrem, Wrocław.

ZAWISTOWSKI K, MICHNIEWICZ M. 2009 - Wody podziemne miast Polski. Miasta powyżej 50000 mieszkańców - Jelenia Góra. Państw. Inst. Geol., Warszawa.

ZIERNICKA A. 2004 - Globalne ocieplenie a efektywność opadów atmosferycznych. Acta Agrophys., 3 (2): 393-397.

ŻELAŹNIEWICZ A., ALEKSANDROWSKI P., BUŁA Z., KARNKOWSKI P.H., KONON A., OSZCZYPKO N., ŚLACZKA A., ŻABA J., ŻYTKO K. 2011 - Regionalizacja tektoniczna Polski. Komitet Nauk Geologicznych PAN, Wrocław. 